Sains Malaysiana 50(4)(2021): 953-965

http://doi.org/10.17576/jsm-2021-5004-07

\title{
Mitochondrial Genome of Rattus tiomanicus (Rodentia: Muridae) and Molecular Phylogeny of Murinae
}

(Genom Mitokondria Rattus tiomanicus (Rodentia: Muridae) dan Filogeni Molekul Murinae)

\author{
SZE-LOOI SONG*, HoI-SEN Yong, PHAIK-EEM LiM \& Ji TAN
}

\begin{abstract}
Rattus tiomanicus is a murid rodent of considerable agricultural and public health importance in Southeast Asia. The whole mitochondrial genome of R. tiomanicus was sequenced by the Ion Torrent PGM platform. It had a total length of 16,309 bp, consisting of 13 protein-coding genes, two rRNA genes, 22 tRNA genes and two non-coding regions (L-strand replication origin and control region). Only TAA and incomplete T-stop codons were represented in the protein-coding genes. Of the tRNAs, tryptophan (W) had ACU anticodon. The cloverleaf structure for serine S1 (AGN) tRNA lacked the entire D-arm, while in lysine $(K)$ tRNA, the DHU arm lacked the D-loop. Molecular phylogeny based on 15 mt-genes indicated $\mathrm{R}$. tiomanicus having closest genetic affinity to R. rattus complex (R. rattus, R. tanezumi). There were two major clades for the Murinae subfamily namely the Rattini tribe and the Apodemini, Murini and Hydromyini tribes. The whole mitogenome of $\mathrm{R}$. tiomanicus will serve as a useful dataset for studying the systematics and phylogenetic relationships of the murid rodents.
\end{abstract}

Keywords: Genomics; Murinae; phylogenetics

\section{ABSTRAK}

Rattus tiomanicus ialah tikus murid yang penting dalam bidang kesihatan dan pertanian di Asia Tenggara. Seluruh genom mitokondria R. tiomanicus telah dijujuk oleh platfom Ion Torrent PGM. Ia mempunyai jumlah panjang 16,309 bp, terdiri daripada 13 gen yang mengekod protein, dua gen rRNA, 22 gen tRNA dan dua kawasan bukan pengekodan (origin replikasi bebenang $L$ dan kawasan pengawalan). Hanya TAA dan kodon penamat tidak lengkap $T$ berada dalam gen yang mengekod protein. Bagi gen tRNA, triptofan (W) mempunyai antikodon ACU. Struktur kelawar bagi tRNA serina S1 (AGN) kekurangan keseluruhan lengan-D, manakala lengan DHU dalam tRNA lisina (K) kekurangan gelung-D. Filogeni molekul berdasarkan gen-mt 15 menunjukkan R. tiomanicus mempunyai pertalian genetik yang paling dekat dengan R. rattus kompleks (R. rattus, R. tanezumi). Dua klad utama untuk subfamili Murinae adalah untuk suku Rattini dan suku Apodemini, Murini serta Hydromyini. Keseluruhan mitogenom R. tiomanicus adalah bermanfaat untuk memberikan set data dalam mengkaji hubungan sistematik dan filogenetik bagi tikus murid.

Kata kunci: Filogenetik; genom; Murinae

\section{INTRODUCTION}

Rattus tiomanicus is a murid rodent of considerable economic and public health importance, as a pest and carrier of disease pathogens, in Southeast Asia. It is a definitive host of the nematode parasites Angiostrongylus cantonensis (Yong \& Eamsobhana 2013), A. malaysiensis (Eamsobhana 2014) and Breinlia tinjili (Purnomo \& Bangs 1996) among others.

The Malaysian field rat $R$. tiomanicus is found in Thailand, Malaysia, Brunei, Indonesia and the
Philippines (Musser \& Carleton 2005), excluding the contentious report of transundaic distribution (Balakirev \& Rozhnov 2012; Robins et al. 2014). The type locality is Tioman Island, off the east coast of Peninsular Malaysia It is represented by many subspecies, both in the mainland as well as the offshore islands. It is a serious pest of plantation crops in Southeast Asia (Buckle et al. 1997).

The karyotype of $R$. tiomanicus from Tioman Island is identical to the mainland $R$. $t$. jalorensis (Yong et al. 1972). It is distinct from the closely related 
congeneric taxa $R$. rattus and $R$. argentiventer (Yong 1969). These congeners are also readily distinguished by their immunoelectrophoretic serum-protein patterns (Yong 1968; Yong \& Dhaliwal 1980). A study based on cytochrome $b(c o b)$ gene indicated that $R$. tiomanicus is closely related to $R$. baluensis, a montane endemic of northwestern Borneo (Aplin et al. 2011).

In addition to DNA nucleotide sequences (Latinne et al. 2013; Lecompte et al. 2008; Pagès et al. 2010; Robins et al. 2014, 2007), whole mitochondrial genomes have been used to infer phylogenetic relationships of the Rattus genus (Robins et al. 2010, 2008). Usage of single or several universal markers for phylogenetic analysis is becoming unfeasible as complete genome sequences will be able to generate a robust phylogeny. To date, there are 13 mitochondrial whole genomes (including the present $R$. tiomanicus) belonging to the Rattus genus deposited in GenBank. We report here the whole mitogenome of $R$. tiomanicus based on next-generation sequencing (NGS) and discuss the molecular phylogeny of Murinae.

\section{MATERIAL AND Methods}

\section{ETHICS STATEMENT}

This research was approved by the UTAR Scientific and Ethical Review Committee (SERC) with approval number of U/SERC/70/2015 and was carried out as in guidelines stated by SERC.

\section{SPECIMEN}

The rat was collected by wire cage trap. It was sacrificed by anesthesia. Small pieces of liver were preserved in absolute ethanol and kept in freezer until use. The rat was identified based on the morphological descriptions from Medway (1983) and Yong et al. (1972).

\section{MITOCHONDRIA ISOLATION AND DNA EXTRACTION}

A small piece of the alcohol-preserved liver tissue was pressed onto a $\mathrm{C}$-fold paper towel to remove excess ethanol before homogenisation. The mitochondria were isolated by standard differential centrifugation method and the mitochondrial DNA (mtDNA) was extracted using Mitochondrial DNA Isolation Kit (Abnova, Taipei, Taiwan) following the manufacturer's instructions. Final DNA was eluted using EB buffer instead of TE buffer to avoid interference of EDTA with the enzyme.

\section{SAMPLE AND LIBRARY PREPARATION}

The purified mtDNA was quantified with a Qubit 2.0 Fluorometer (Life Technologies, USA) using the Quant-iT
dsDNA HS Assay Kit (Life Technologies, USA). A total of $100 \mathrm{ng}$ of mtDNA was enzymatically fragmented using Ion Shear ${ }^{\mathrm{TM}}$ Plus Reagents (Life Technologies, USA) following the manufacturer's protocol. For 400-base-read library, incubation time was set to 6 min to yield median fragment size of 350 to $450 \mathrm{bp}$. Ion adapters were ligated to the fragmented mtDNA using the Ion Plus Fragment Library Kit (Life Technologies, USA) followed by nick repair. The library was size-selected using the $2.0 \%$ E-Gel SizeSelect ${ }^{\mathrm{TM}}$ Agarose Gel (Life Technologies, USA) following the manufacturer's recommendations. The quality, size distribution and concentration of the library were determined using the Agilent 2200 TapeStation (Agilent Technologies, Inc.) prior to template preparation to ensure library was within the recommended size range of the template kit used, as well as to minimise the polyclonal values of the sequencing results.

\section{TEMPLATE PREPARATION}

The library was diluted to a final concentration of 26 $\mathrm{pM}$ and subjected to emulsion PCR using the Ion PGM ${ }^{\mathrm{TM}}$ Template OT2 400 Kit and Ion OneTouch ${ }^{\text {TM }} 2$ System (Life Technologies, USA) to generate template-positive Ion Sphere ${ }^{\mathrm{TM}}$ Particles (ISPs) containing clonally amplified DNA. The template-positive ISPs were recovered and quantified using the Ion Sphere quality control kit (Life Technologies) and Qubit 2.0 fluorometer (Life Technologies) according to the manufacturer's recommendations. The percentage of template-positive ISPs fell within the optimal range of $10-30 \%$ was subsequently enriched with Dynabeads Myone streptavidin C1 beads (Life Technologies) using the Ion One-Touch ${ }^{\mathrm{TM}}$ ES (Life Technologies, USA) following the manufacturer's protocol.

\section{PGM SEQUENCING}

Chlorite cleaning procedures followed by a wash with $18 \mathrm{M} \Omega$ water were performed before initialising the PGM Sequencer. The template-positive ISPs were loaded onto Ion $316^{\mathrm{TM}} \mathrm{V} 2$ Chip and sequenced using the Ion $\mathrm{PGM}^{\mathrm{TM}} 400$ Sequencing Kit (Life Technologies) on Ion Torrent Personal Genome Machine (PGM) System (Life Technologies) following the manufacturer's protocols.

\section{SEQUENCE AND GENOME ANALYSIS}

Raw sequences were extracted from the Torrent Server in FASTQ format and the quality of sequences was evaluated using the FastQC software (Andrews 2010). All the ambiguous nucleotides and reads with an average quality value (lower than Q20) were excluded from 
further analysis. De novo assembly was performed using the CLC Genomic Workbench v.7.0.4 (https://www. qiagenbioinformatics.com/) and contigs greater than $15 \mathrm{kbp}$ were subjected to BLAST (Altschul et al. 1990) alignment against the nucleotide database at National Center for Biotechnology Information (NCBI).

The three domains (ETAS, CD, and CSB) and main subsequences of the control region (CR, D-loop) were ascertained by reference to those reported for $R$. norvegicus and other rodents (Abhyankar et al. 2009; Gemmell et al. 1996; Larizza et al. 2002; Sbisà et al. 1997; Silva et al. 2011).

\section{MITOGENOME IDENTIFICATION, ANNOTATION AND VISUALISATION}

The assembled contig identified as mitogenome was manually examined for repeats at the beginning and end of the sequence to infer circularity. The mitogenome was then annotated with MITOS (http://mitos.bioinf.uni-leipzig.de/ index.py) (Bernt et al. 2012) followed by manual validation of the coding regions using the NCBI ORF Finder (http:// www.ncbi.nlm.nih.gov/gorf/gorf.html). The sequin file generated from MITOS was edited and submitted to NCBI according to ORF Finder result (NCBI GenBank accession number KP876560 and NC_029888). The circular mitogenome of $R$. tiomanicus was visualised with Blast Ring Image Generator (BRIG) (Alikhan et al. 2011).

\section{PHYLOGENETIC ANALYSIS}

Mitogenome sequences (36 species) of Muridae family available in GenBank were used to construct phylogenetic trees. Pteromys volans NC_019612 (Ryu et al. 2013) and Ratufa bicolor NC_023780 (Kong et al. 2015) of the Sciuridae family were included as outgroup taxa. The 15 mt-gene sequences were aligned using MAFFT multiple sequence alignment software v.7 (Katoh \& Standley 2013) and subsequently edited and trimmed using BioEdit v.7.0.5.3 (Hall 1999). Kakusan v.3 (Tanabe 2007) was used to determine the best-fit nucleotide substitution models for maximum likelihood (ML) and Bayesian (BI) analyses selected using the corrected Akaike Information Criterion (Akaike 1973) and the Bayesian Information Criterion (Schwarz 1978), respectively. Phylograms of $15 \mathrm{mt}$-genes were constructed using TreeFinder (Jobb et al. 2004) prior to the annotations of bootstrap values (BP) generated via 1,000 ML bootstrap replicates. Bayesian analyses on the concatenated amino acid sequence data for all $15 \mathrm{mt}$-genes were conducted using the Markov chain Monte Carlo (MCMC) method via Mr. Bayes v.3.1.2 (Huelsenbeck \& Ronquist 2001). Two independent runs of $2 \times 10^{6}$ generations with four chains were performed, with trees sampled every 200th generation. Likelihood values for all post-analysis trees and parameters were evaluated for convergence and burn-in using the 'sump' command in MrBayes and the computer program Tracer v.1.5 (http:// tree.bio.ed.ac.uk/software/tracer/). The first 200 trees from each run were discarded as burn-in (where the likelihood values were stabilized prior to the burn-in), and the remaining trees were used for the construction of a $50 \%$ majority-rule consensus tree. FigTree v.1.4 was used to view and edit the final phylogenetic trees (Rambaut 2012).

\section{RESUlTS AND DisCUSSION}

\section{GENOME FEATURES}

The Rattus genus is represented by some 64 species in the world (Musser \& Carleton 2005). To date, the complete mitogenomes of 13 species (including the present $R$. tiomanicus) have been sequenced and available in GenBank. This made up nearly one-third of the complete mitogenomes of 36 species for the Muridae family. Most of these complete mitogenomes have been sequenced by means of the long polymerase chain reaction (long-PCR) technique (Robins et al. 2010, 2008; Wang et al. 2015; Yong et al. 2016; Zhu et al. 2016). In this study, we sequenced and reported for the first time the complete mitogenome of $R$. tiomanicus by NGS using the Ion Torrent PGM platform. The results were consistent with reported rodent mitogenomes based on long-PCR. In comparison to other methods such as long-PCR, Sanger sequencing and Illumina platform, Ion Torrent PGM platform is performed by using semiconductor chip which is fast, simple and cost effective. Similar to other NGS platforms, Ion Torrent PGM produces large amounts of DNA sequence data in a short period of time.

Next-generation sequencing on Ion Torrent PGM platform generated a total of 1,440,186 sequence reads, with an average length of 159 bases and a total of $229,400,258$ bases. Removal of low quality sequence, ambiguous nucleotides and sequences shorter than 50 nucleotides resulted in 13,709 contigs with 5,194,894 bases. The contig maximum length was 16,309 bp and N50 was $383 \mathrm{bp}$. The total GC content was $46.7 \%$, with base composition of $34.2 \% \mathrm{~A}, 27.8 \% \mathrm{~T}, 12.5 \% \mathrm{G}$, and $25.5 \% \mathrm{C}$. The mitogenome of $R$. tiomanicus was 16,309 bp long consisting of 37 genes (13 PCGs, two rRNA genes and 22 tRNA genes) as well as two non-coding regions (L-strand replication origin and control region) (Table $1 \&$ Figure 1). Spacing sequences ranged from 1 to $5 \mathrm{bp}$ in 14 regions. The overlaps in seven regions ranged from 1 to $43 \mathrm{bp}$, the largest being between atp 8 and atp6 (Table 1). Nine genes (one protein-coding gene nad6; eight tRNA genes) were 
located on the light-strand. The L-strand replication origin $\left(\mathrm{O}_{\mathrm{L}}\right)$ was located in the WANCY cluster between $\operatorname{trn} N$ and $\operatorname{trn} C$ (Table $1 \&$ Figure 1), with $31 \mathrm{bp}$ as in other species of the Rattus genus (Table 2). It had two base substitutions
- a transversion ( $\mathrm{T}$ to $\mathrm{A}$ ) at position 14 (also in $R$. rattus and $R$. tanezumi), and a transition ( $\mathrm{C}$ to $\mathrm{T})$ at position 15 compared to other congeners (Table 2).

TABLE 1. Characteristics of the mitochondrial genome of Rattus tiomanicus. Three nucleotides in parentheses denotes the anticodon

\begin{tabular}{|c|c|c|c|c|c|}
\hline Gene & Location & Strand & Size (bp) & $\begin{array}{l}\text { Intergenic } \\
\text { sequence }\end{array}$ & $\begin{array}{c}\text { Start/Stop } \\
\text { codon }\end{array}$ \\
\hline $\operatorname{trn} F($ gaa $)$ & $1-69$ & $\mathrm{H}$ & 69 & & \\
\hline$r r n S$ & $70-1031$ & $\mathrm{H}$ & 962 & & \\
\hline $\operatorname{trn} V(\mathrm{tac})$ & $1032-1099$ & $\mathrm{H}$ & 68 & & \\
\hline$r r n L$ & $1100-2665$ & $\mathrm{H}$ & 1566 & & \\
\hline $\operatorname{trnL2(taa)}$ & $2666-2740$ & $\mathrm{H}$ & 75 & & \\
\hline nadl & $2741-3695$ & $\mathrm{H}$ & 955 & & GTG/T \\
\hline $\operatorname{trn} I$ (gat) & $3696-3764$ & $\mathrm{H}$ & 69 & -3 & \\
\hline $\operatorname{trn} Q(\operatorname{ttg})$ & $3762-3832$ & $\mathrm{~L}$ & 71 & 3 & \\
\hline $\operatorname{trn} M$ (cat) & $3836-3904$ & $\mathrm{H}$ & 69 & & \\
\hline nad2 & $3905-4940$ & $\mathrm{H}$ & 1036 & & $\mathrm{ATA} / \mathrm{T}$ \\
\hline $\operatorname{trn} W(\mathrm{tca})$ & $4941-5006$ & $\mathrm{H}$ & 66 & 1 & \\
\hline $\operatorname{trn} A(\operatorname{tgc})$ & $5008-5076$ & L & 69 & 2 & \\
\hline $\operatorname{trn} N(\mathrm{gtt})$ & $5079-5150$ & $\mathrm{~L}$ & 72 & & \\
\hline $\mathrm{O}_{\mathrm{L}}$ & $5151-5181$ & $\mathrm{~L}$ & 31 & & \\
\hline $\operatorname{trn} C(\mathrm{gca})$ & $5182-5248$ & L & 67 & 3 & \\
\hline $\operatorname{trn} Y($ gta $)$ & $5252-5317$ & $\mathrm{~L}$ & 66 & 1 & \\
\hline $\operatorname{cox} 1$ & $5319-6863$ & $\mathrm{H}$ & 1545 & -3 & ATG/TAA \\
\hline $\operatorname{trn} S 2$ (tga) & $6861-6929$ & L & 69 & 3 & \\
\hline $\operatorname{trn} D(\mathrm{gtc})$ & $6933-7000$ & $\mathrm{H}$ & 68 & 3 & \\
\hline $\operatorname{cox} 2$ & $7002-7685$ & $\mathrm{H}$ & 684 & 3 & ATG/TAA \\
\hline $\operatorname{trn} K(\mathrm{ttt})$ & $7689-7752$ & $\mathrm{H}$ & 64 & 1 & \\
\hline atp 8 & $7754-7957$ & $\mathrm{H}$ & 204 & -43 & ATG/TAA \\
\hline atp6 & $7915-8595$ & $\mathrm{H}$ & 681 & -1 & ATG/TAA \\
\hline $\operatorname{cox} 3$ & $8595-9378$ & $\mathrm{H}$ & 784 & & $\mathrm{ATG} / \mathrm{T}$ \\
\hline $\operatorname{trn} G(\mathrm{tcc})$ & $9379-9446$ & $\mathrm{H}$ & 68 & & \\
\hline nad3 & $9447-9794$ & $\mathrm{H}$ & 348 & 1 & ATC/TAA \\
\hline $\operatorname{trn} R(\operatorname{tcg})$ & $9796-9863$ & $\mathrm{H}$ & 68 & 2 & \\
\hline nad4l & $9866-10162$ & $\mathrm{H}$ & 297 & -7 & ATG/TAA \\
\hline nad4 & $10156-11533$ & $\mathrm{H}$ & 1378 & & $\mathrm{ATG} / \mathrm{T}$ \\
\hline $\operatorname{trn} H(\mathrm{gtg})$ & $11534-11601$ & $\mathrm{H}$ & 68 & & \\
\hline $\operatorname{trnS} 1$ (gct) & $11602-11660$ & $\mathrm{H}$ & 59 & -1 & \\
\hline $\operatorname{trnL1}$ (tag) & $11660-11730$ & $\mathrm{H}$ & 71 & & \\
\hline nad5 & $11731-13560$ & $\mathrm{H}$ & 1830 & -23 & ATA/TAA \\
\hline nad6 & $13538-14056$ & $\mathrm{~L}$ & 519 & & ATG/TAA \\
\hline $\operatorname{trn} E(\mathrm{ttc})$ & $14057-14125$ & $\mathrm{~L}$ & 69 & 5 & \\
\hline$c o b$ & $14131-15273$ & $\mathrm{H}$ & 1143 & 1 & ATG/TAA \\
\hline $\operatorname{trn} T(\operatorname{tgt})$ & $15275-15341$ & $\mathrm{H}$ & 67 & 2 & \\
\hline $\operatorname{trn} P(\operatorname{tgg})$ & $15344-15411$ & $\mathrm{~L}$ & 68 & & \\
\hline Control region & $15412-16309$ & $\mathrm{H}$ & 898 & & \\
\hline
\end{tabular}




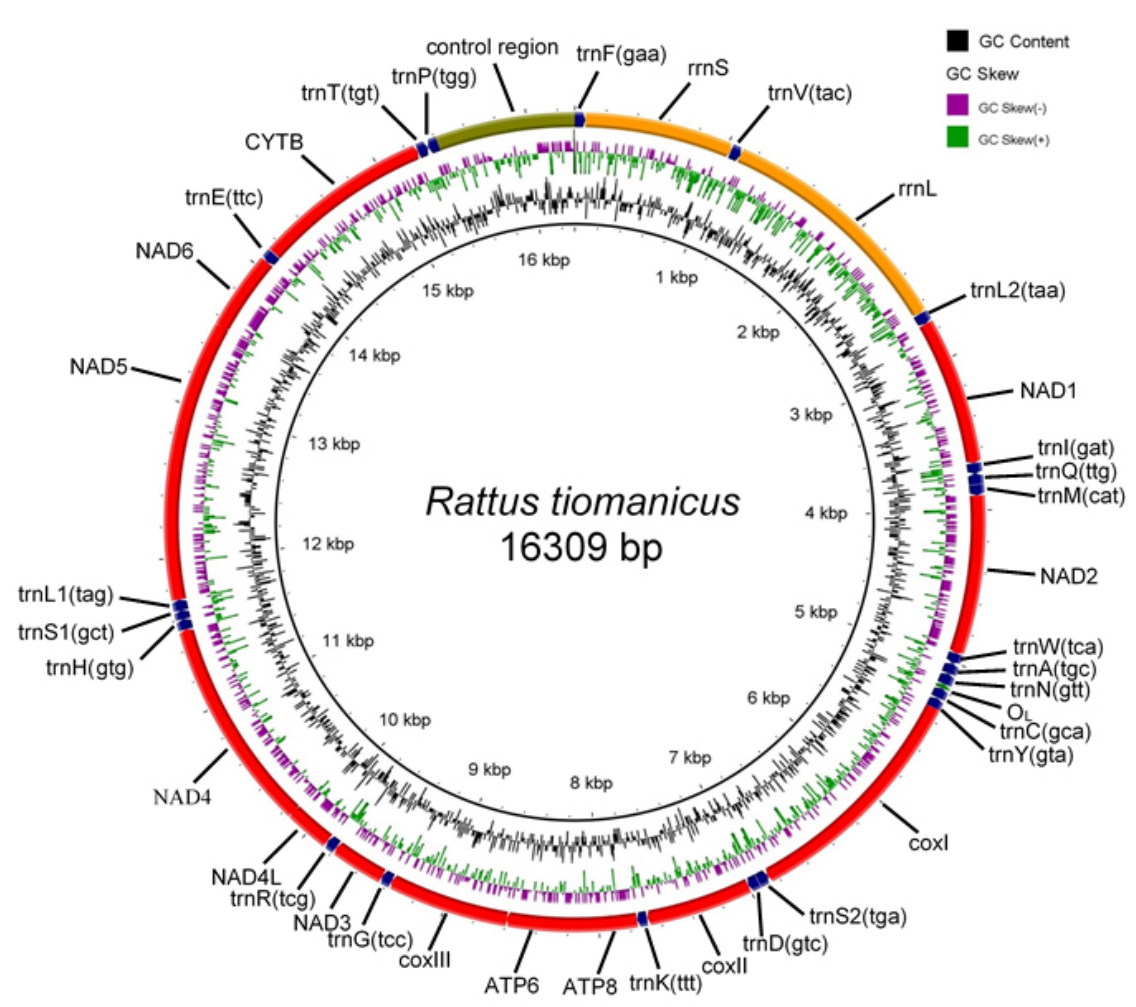

FIGURE 1. Complete mitogenome of Rattus tiomanicus with BRIG visualisation. It shows the protein coding genes, rRNAs, tRNAs and non-coding regions. GC skew is shown on the outer surface of the ring whereas GC content is shown on the inner surface

TABLE 2. Alignment of the L-strand Replication Origin sequences of $R$. tiomanicus and congeners with reference to R. norvegicus. Base substitutions at positions 14 and 15 with reference to $R$. norvegicus are highlighted

\begin{tabular}{|c|c|}
\hline Species & Nucleotide sequence \\
\hline R. tiomanicus & CTTCTCCCGCCTAATAGAAAAGAGGCGGGAG \\
\hline R. rattus NC_012374 & СTTCTCCCGCCTAACAGAAAAGAGGCGGGAG \\
\hline R. tanezumi NC_011638 & СTTCTCCCGCCTAACAGAAAGGGGGCGGGAG \\
\hline R. norvegicus KF011917 & CTTCTCCCGCCTATCAGAAAAGAGGCGGGAG \\
\hline R. exulans NC_012389 & CTTCTCCCGCCTATCAGAAAAGGGGCGGGAG \\
\hline R. fuscipes NC_014867 & CTTCTCCCGCCTATCAGAAAAGAGGCGGGAG \\
\hline R. leucopus NC_014855 & CTTCTCCCGCCTATCAGAAAAGAGGCGGGAG \\
\hline R. lutreolus NC_014858 & CTTCTCCCGCCTATCAGAAAAGAGGCGGGAG \\
\hline R. niobe $\mathrm{NC} \_023347$ & СТTCTCCCGCCTATCAGAAAAGAGGCGGGAG \\
\hline R. praetor $\mathrm{NC} 012461$ & СТTCTCCCGCCTATCAGAAAAGAGGCGGGAG \\
\hline R. sordidus NC_014871 & СТTCTCCCGCCTATCAGAAAAGAGGCGGGAG \\
\hline R. tunneyi NC_014861 & СТTCTCCCGCCTATCAGAAAAGAGGCGGGAG \\
\hline R. villosissimus $\mathrm{NC} 014864$ & СТTCTCCCGCCTATCAGAAAAGAGGCGGGAG \\
\hline
\end{tabular}


The control region ( $898 \mathrm{bp}$ ) was flanked by trnP and $\operatorname{trnF}$ (Figure 1). It conformed to the general scheme of the D-loop structure in rodents, comprising the ETAS (extended termination-associated sequences) domain
(ETAS1 and ETAS2), CD - central domain (subsequences $\mathrm{A}, \mathrm{B}$ and $\mathrm{C}$ ), and CSB (conserved sequence block) domain (CSB1, CSB2 and CSB3) (Figure 2).

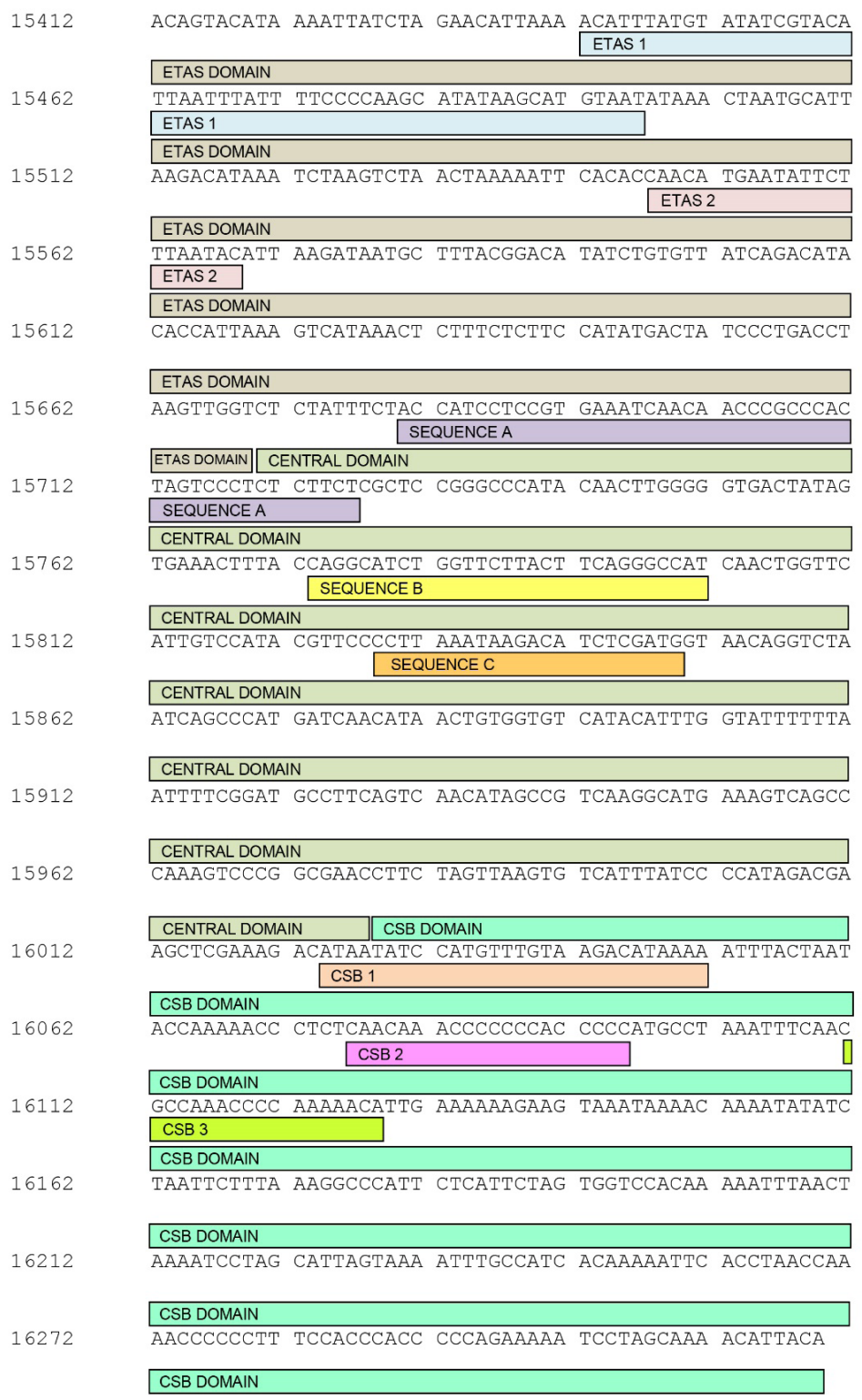

FIGURE 2. Control region in the mitogenome of Rattus tiomanicus. ETAS (bp position: 15412-15669), extended termination-associated sequences; Central domain (bp position: 15670-15977); CSB (bp position: 15978-16309), conserved sequence block. ETAS1: 15442-15496; ETAS2: 15547-15568; Sequence A: 15680-15726; Sequence B: 15773-15801; Sequence C: 15828-15849; CSB 1: 16024-16051; CSB 2: 16076-16095; CSB 3: 16111-16228 
The commonest start codon was ATG (in nine proteincoding genes - cox1, cox2, atp8, atp6, cox3, nad4l, nad4, nad6, cob), followed by two for ATA (nad2, nad5), and one each for ATC (nad3) and GTG (nadl). Nine proteincoding genes had TAA stop codon while the remaining four genes (nad1, nad2, cox3, nad4) had incomplete Tstop codon (Table 1).
Of the tRNAs, trn $W$ had ACU anticodon instead of the canonical Trp tRNA ACC anticodon (Table $1 \&$ Figure 3). The cloverleaf structure for trnS1 lacked the entire D-arm, while in trnK the DHU arm lacked the D-loop (Figure 3). The number of base pairs in the DHU-stem ranged from 2 to 4 except none in trnS1 (Figure $3 \&$

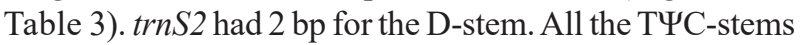
had 5 base pairs except 4 bp in trnW.
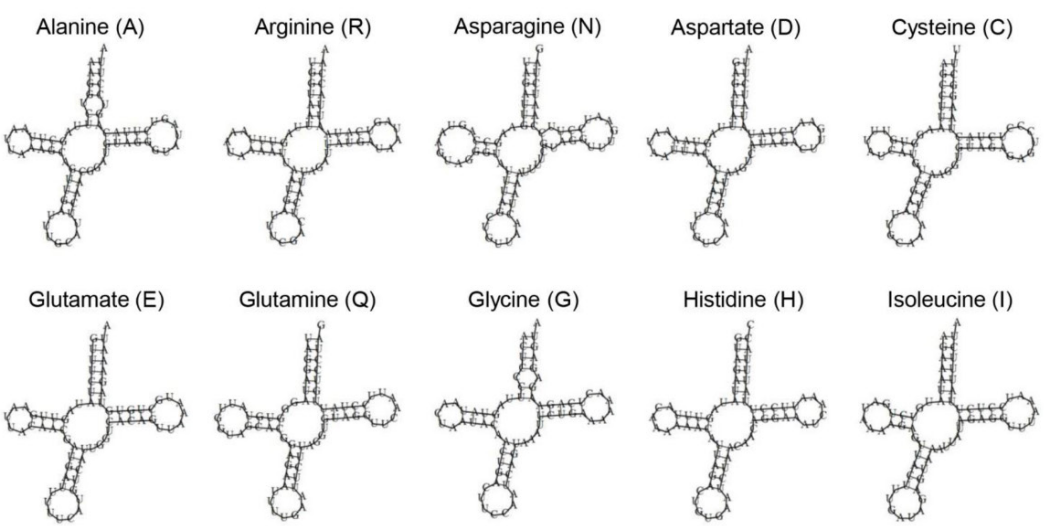<smiles>CC1CC(=C2CCCC2)CC(=C2CCCC2)C1</smiles><smiles>C1CCCC1</smiles><smiles>N#C[C]C1CCCC1C1CCCC1</smiles>

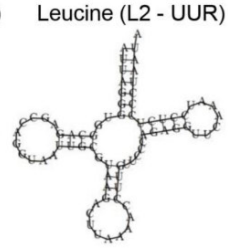<smiles>C=C1C(=C2CCCC2)CC(C#N)CC1C</smiles>

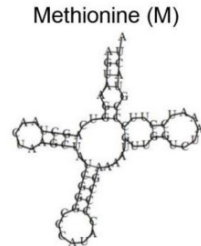

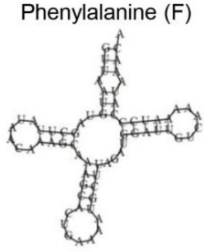<smiles>CCC1CC(=C2CCCC2)CC(C2CC2)C1</smiles>

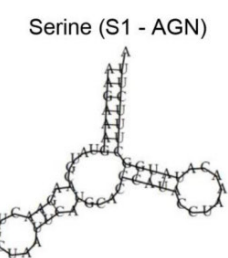<smiles>N#C[GeH]1CCCC1</smiles>

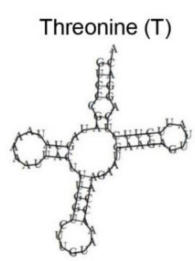

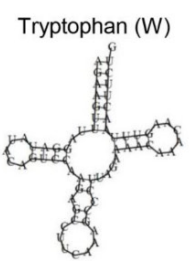<smiles>CC1C(=C2CCCC2)CC(C2CCC2)NC1C#N</smiles>

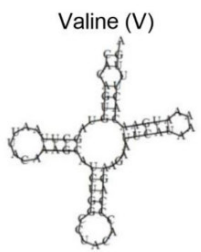

FIGURE 3. Cloverleaf structure of the 22 inferred tRNAs in the mitogenome of Rattus tiomanicus. Note atypical secondary structure of lysine with the DHU arm lacking the D-loop and serine S1 without the entire D-arm 


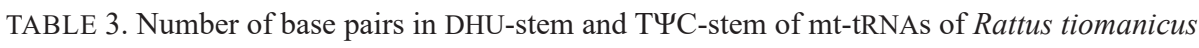

\begin{tabular}{|c|c|c|}
\hline tRNA & DHU-stem & 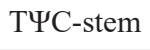 \\
\hline Alanine & 4 & 5 \\
\hline Arginine & 4 & 5 \\
\hline Asparagine & 3 & $5^{\#}$ \\
\hline Aspartate & 4 & 5 \\
\hline Cysteine & 3 & 5 \\
\hline Glutamate & 3 & 5 \\
\hline Glutamine & 3 & 5 \\
\hline Glycine & 4 & 5 \\
\hline Histidine & 4 & 5 \\
\hline Isoleucine & 3 & 5 \\
\hline Leucine L1 (CUN) & 4 & 4 \\
\hline Leucine L2 (UUR) & 4 & 5 \\
\hline Lysine & $4^{*}$ & 5 \\
\hline Methionine & 4 & $5^{\#}$ \\
\hline Phenylalanine & 4 & 5 \\
\hline Proline & 4 & 5 \\
\hline Serine S1 (AGN) & absent & 5 \\
\hline Serine S2 (UCN) & 2 & 5 \\
\hline Threonine & 3 & 5 \\
\hline Tryptophan & 4 & 4 \\
\hline Tyrosine & 3 & 5 \\
\hline Valine & 4 & 5 \\
\hline
\end{tabular}

*without D-loop; "with small inner loop

The size of the $R$. tiomanicus mitogenome $(16,309$ $\mathrm{bp}$ ) is similar to other species of the Rattus genus (range of 16,292 to $16,310 \mathrm{bp}$ ) and other murid genera (range of 16,217 to $16,351 \mathrm{bp}$ ) that are available in GenBank. In this $R$. tiomanicus mitogenome, only TAA and incomplete T-stop codons were represented in the protein-coding genes (Table $1 \&$ Figure 2). The stop codons in $R$. tiomanicus differ from other rodent mitogenomes which possess additionally TAG stop codon (Chao et al. 2014; Jiang et al. 2012; Kim \& Lee 2016; Kong et al. 2015) and other stop codons - AGG and AGA (Ryu et al. 2013); and TAT, CAT and CTT (Zhao et al. 2014). The incomplete T- stop codons can be converted to TAA by post-translational polyadenylation (Ojala et al. 1981).

As in other vertebrates, the $R$. tiomanicus mitogenome has three clusters of characteristic tRNAs (Figure 1) which were IQM (isoleucine, glutamate, and methionine), WANCY (tryptophan, alanine, aspartic acid, cysteine, and tyrosine) and HSL (histidine, serine, and leucine) (Pereira 2000). Among the unusual features of the tRNAs are the presence of ACU anticodon in trnW, absence of the entire D-arm for trnS1, and absence of D-loop in the DHU arm of trnK. The ACU anticodon is present in 12 other congeners of the Rattus genus (Figure 
4). The atypical cloverleaf structures of trnS1 and trnK are also found in the Arvicolinae rodent Microtus fortis calamorum (Jiang et al. 2012). Indeed, the absence of DHU arm in trnS1 is common in all vertebrates and a reduced $\mathrm{D}$-arm in $\operatorname{trn} K$ is shared by placental and marsupial mammals (Pereira 2000).

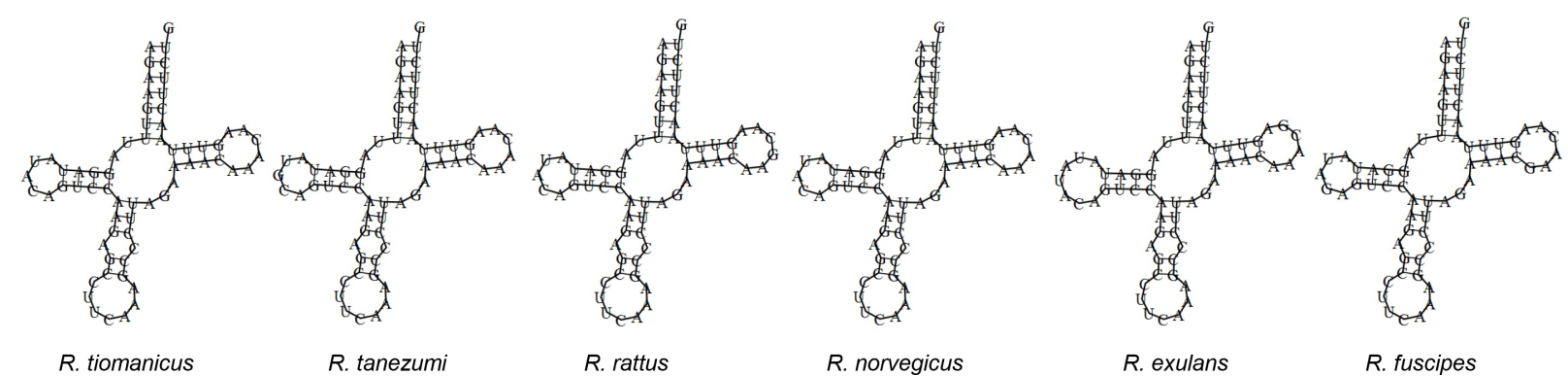

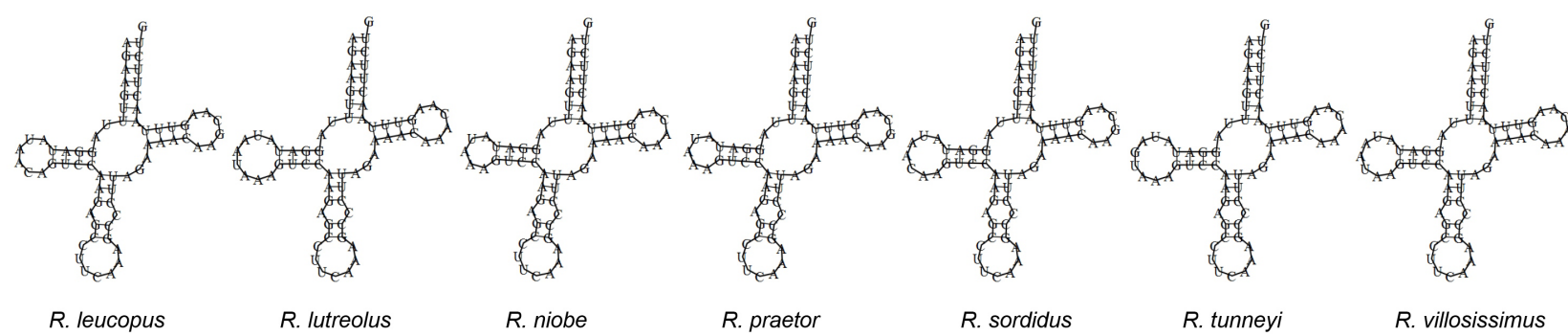

FIGURE 4. Secondary structure of tryptophan sequences of Rattus tiomanicus and congeners. It shows identical ACU anticodon (opal suppressor) instead of the canonical Trp tRNA ACC anticodon

\section{PHYLOGENETIC RELATIONSHIPS WITHIN MURINAE}

The total length of the aligned sequences of $15 \mathrm{mt}$-genes (13 PCGs, two rRNA genes) was 14,222 bp and the selected models used for maximum likelihood (ML) and Bayesian Inference (BI) analyses were GTR+Gamma and SYM + Gamma, respectively. The molecular phylogeny of $R$. tiomanicus in relation to other taxa of the Murinae subfamily is depicted in Figure 5. Most of the nodes were well-supported. There were two major clades for the Murinae subfamily namely the Rattini tribe comprising Rattus and Dacnomys divisions, and Apodemini tribe (Apodemus division), Murini tribe (Mus division) and Hydromyini tribe (Psuedomys division), with Apodemus division and Mus division having closer affinity than Pseudomys division. R. tiomanicus showed closer genetic affinity to $R$. rattus and $R$. tanezumi than to $R$. exulans and $R$. norvegicus.

Phylogenetic analysis based on DNA nucleotide sequences, particularly D-loop, cytochrome $b(c o b)$ and cytochrome oxidase I ( $\operatorname{cox} 1)$, assigned $R$. tiomanicus to a phylogenetic group distinct from Rattus rattus species complex (Latinne et al. 2013; Pagès et al. 2010; Robins et al. 2014, 2007). It is closely related to $R$. baluensis forming Lineage VI in a clade with Lineage IV (Rattus rattus) and Lineage V (Rattus sakeratensis) (Aplin et al. 2011).

In the present study, the molecular phylogeny based on $15 \mathrm{mt}$-genes (Figure 5) showed two lineages in the Rattus division which were Asian and Island Southeast Asian Rattus species, and Australo-Papuan Rattus species. This phylogenetic relationship is in accordance with the findings based on D-loop, cob and cox 1 sequences (Robins et al. 2007), D-loop and coxl sequences (Robins et al 2014) and whole mitochondrial genome (Robins et al. 2010). The closer affinity of $R$. tiomanicus with $R$. rattus and $R$. tanezumi than to $R$. exulans and $R$. norvegicus is congruent with findings based on D-loop, cob and cox 1 sequences (Latinne et al. 2013; Pagès et al. 2010; Robins et al. 2014, 2007). 


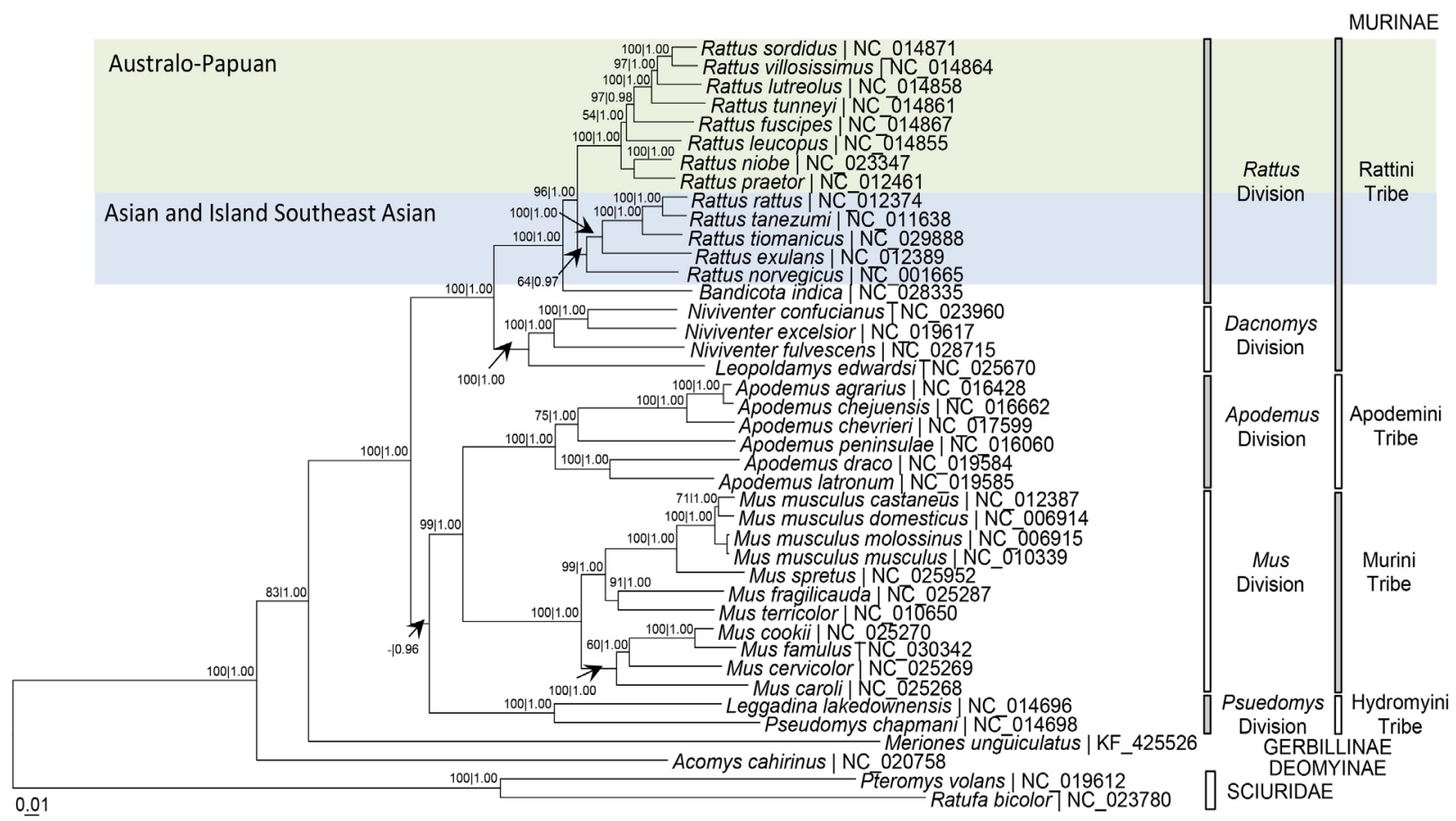

FIGURE 5. BI and ML tree based on 15 mt-genes (13 PCGs, two rRNA genes) of the whole mitogenomes of murid rodents. Numeric values at the nodes are Bayesian posterior probabilities/ML bootstrap

The phylogenetic relationships of the AustraloPapuan Rattus species based on 15 mt-genes (Figure 5) were in general agreement with the findings based on D-loop, cob and coxl sequences (Robins et al. 2007) and D-loop and coxl sequences (Robins et al. 2014), but not congruent with the findings based on $c o b$, GHR (growth hormone receptor exon 10) and IRPB (interphotoreceptor retinoid binding protein exon1) sequences (Fabre et al. 2013). Our results were also in general agreement with the findings based on whole mitogenome datasets of seven species (Robins et al. 2010). A major difference is the inclusion of $R$. niobe mitogenome in our analysis resulting in the close affinity of $R$. praetor and $R$. niobe instead of $R$. praetor with $R$. fuscipes. However, the topology of the phylogenetic tree may change when mitogenomes of other taxa become available for study. To date, the study based on D-loop and cox 1 sequences indicated that $R$. praetor, $R$. niobe, and $R$. verecundus each likely encompass more than one species (Robins et al. 2014).

Our present findings of Bandicota indica being basal to the Rattus genus in the Rattus Division and of Leopoldamys edwardsi being basal to the Niviventer genus in the Dacnomys Division (Figure 5) concurred with earlier studies (Wang et al. 2015; Yong et al. 2016).

The Murinae phylogeny in the present study was congruent with that based on $c o b$, IRBP and GHR genes
(Lecompte et al. 2008) although the datasets are different. The phylogeny of the Apodemus genus based on $15 \mathrm{mt}-$ genes (Figure 5) of available whole mitogenomes shows good concordance with that based on $c o b$ sequences (Liu et al. 2012), comprising two subgroups in the Apodemus group namely agrarius subgroup consisting of $A$. agrarius, $A$. chejuensis, $A$. chevrieri, and $A$. peninsulae, and draco subgroup consisting of $A$. draco and A. latronum. Our study showed additionally close affinity of $A$. agrarius and $A$. chejuensis where the taxon chejuensis was earlier treated as a subspecies of $A$. agrarius but found to be valid species based on differences in mitochondrial control region sequences and morphology (Koh et al. 2000). The topology of the phylogeny of the Apodemus group based on $15 \mathrm{mt}$-genes (Figure 5) and cob sequences (Liu et al. 2012) differed from that inferred from cob, IRBP, RAGI (recombination activating gene 1), I7 (an olfactory receptor) and vWF (von Willebrand factor) genes (Suzuki et al. 2008) which showed closer affinity of $A$. peninsulae to the draco subgroup.

In the present study, 11 taxa of the Mus genus with complete mitogenomes have been included for analysis (Figure 5). The overall phylogenetic relationship was congruent with that inferred from $c o b, 12 \mathrm{~S}, \mathrm{~B} 2 \mathrm{~m}$ (B2microglobulin), Zp3 (zona pellucida-3), Tcp1 (t-complex polypeptide-1), Sry (sex determining locus), Smcx 
(member of jumonji family of transcription factors) and Smcy (selected mouse cDNA Y) sequences (Tucker et al. 2005). Our analysis included additionally M. famulus, M. fragilicauda and M. terricolor. M. fragilicauda and M. terricolor are sister taxa and form a clade with $M$. musculus and M. spretus, while M. famulus is sister to $M$. cookii in the lineage comprising also $M$. caroli and $M$. cervicolor (Figure 5).

At the subfamily level based on $15 \mathrm{mt}$-genes (Figure 5), Gerbillinae showed closer affinity to Murinae than Deomyinae. This differed from the findings of Gerbillinae and Deomyinae (Acomyinae) being sister taxa inferred from slower evolving IRBP gene sequences (Jansa \& Weksler 2004) and nuclear protein-coding LCAT (lecithin cholesterol acyl transferase) and vWF genes (Michaux et al. 2001). More extensive taxa sampling of some under-represented and unrepresented subfamilies was needed to resolve the phylogenetic relationships of the murid subfamilies.

\section{CONCLUSION}

In summary, we have successfully sequenced the whole mitochondrial genome of $R$. tiomanicus by next-generation sequencing. The genome features were similar to other rodents except that only TAA and incomplete T-stop codons were represented in the protein-coding genes, and the presence of ACU anticodon in $\operatorname{trn} W$. Based on $15 \mathrm{mt}-$ genes of the mitogenome, $R$. tiomanicus showed closest genetic affinity to $R$. rattus and $R$. tanezumi. There were two major clades for the Murinae subfamily namely Rattini tribe, and Apodemini, Murini and Hydromyini tribes. The tribes/divisions of the Murinae subfamily were monophyletic. At the subfamily level, Gerbillinae showed closer affinity to Murinae than to Deomyinae. The whole mitogenome of $R$. tiomanicus will serve as a useful dataset for studying the systematics and phylogenetic relationships of the many subspecies of $R$. tiomanicus in particular, and murid rodents in general.

\section{DATA AVAILABILITY STATEMENT}

The whole mitochondrial genome sequence of $R$. tiomanicus is available in GenBank database (accession number: KP876560 and NC_029888). The authors have declared no conflicts of interest.

\section{ACKNOWLEDGEMENTS}

This study was funded in part by MOHE-HIR Grant (H-50001-00-A000025) and the University of Malaya (H5620009). We thank our institutions for providing various research facilities and other support.

\section{REFERENCES}

Abhyankar, A., Park, H.B., Tonolo, G. \& Luthman, H. 2009. Comparative sequence analysis of the non-protein-coding mitochondrial DNA of inbred rat strains. PLOS ONE 4(12): e8148.

Akaike, H. 1973. Information theory and an extension of the maximum likelihood principle. In Second International Symposiumon Information Theory, edited by Csaki, F. \& Petrov, B.N. Budapest: Akademia Kiado. pp. 267-281.

Alikhan, N.F., Petty, N.K., Ben Zakour, N.L. \& Beatson, S.A. 2011. BLAST Ring Image Generator (BRIG): Simple prokaryote genome comparisons. BMC Genomics 12(1): 402.

Altschul, S.F., Gish, W., Miller, W., Myers, E.W. \& Lipman, D.J. 1990. Basic local alignment search tool. Journal of Molecular Biology 215(3): 403-410.

Andrews, S. 2010. FastQC: A Quality Control Tool for High Throughput Sequence Data. Cambridge: Babraham Institute.

Aplin, K.P., Suzuki, H., Chinen, A.A., Chesser, R.T., Ten Have, J., Donnellan, S.C., Austin, J., Frost, A., Gonzalez, J.P., Herbreteau, V., Catzeflis, F., Soubrier, J., Fang, Y.P., Robins, J., Matisoo-Smith, E., Bastos, A.D., Maryanto, I., Sinaga, M.H., Denys, C., Van Den Bussche, R.A., Conroy, C., Rowe, K. \& Cooper, A. 2011. Multiple geographic origins of commensalism and complex dispersal history of black rats. PLoS ONE 6(11): e26357.

Balakirev, A. \& Rozhnov, V.V. 2012. Contribution to the species composition and taxonomic status of some Rattus inhabiting Southern Vietnam and Sundaland. Russian Journal of Teriology 11(1): 33-45.

Bernt, M., Donath, A., Juhling, F., Externbrink, F., Florentz, C., Fritzsch, G., Pütz, J., Middendorf, M. \& Stadler, P.F. 2012. MITOS: Improved de novo metazoan mitochondrial genome annotation. Molecular Phylogenetics and Evolution 69(2): 313-319.

Buckle, A.P., Chia, T.H., Fenn, M.G.P. \& Visvalingam, M. 1997. Ranging behaviour and habitat utilisation of the Malayan wood rat (Rattus tiomanicus) in an oil palm plantation in Johore, Malaysia. Crop Protection 16(5): 467-473.

Chao, Q.J., Li, Y.D., Geng, X.X., Zhang, L., Dai, X., Zhang, X., Li, J. and Zhang, H.J. 2014. Complete mitochondrial genome sequence of Marmota himalayana (Rodentia: Sciuridae) and phylogenetic analysis within Rodentia. Genetics and Molecular Research 13(2): 2739-2751.

Eamsobhana, P. 2014. The Rat Lungworm Angiostrongylus Cantonensis: Parasitology, Genetics and Molecular Phylogeny (2nd ed.). Bangkok: Aksorn Graphic and Design Publishing House.

Fabre, P.H., Pagès, M., Musser, G.G., Fitriana, Y.S., Fjeldså, J., Jennings, A., Jønsson, K.A., Kennedy, J., Michaux, J., Semiadi, G., Supriatna, N. \& Helgen, K.M. 2013. A new genus of rodent from Wallacea (Rodentia: Muridae: Murinae: Rattini), and its implication for biogeography and Indo-Pacific Rattini systematics. Zoological Journal of the Linnean Society 169(2): 408-447. 
Gemmell, N.J., Western, P.S., Watson, J.M. \& Graves, J.A 1996. Evolution of the mammalian mitochondrial control region - comparisons of control region sequences between monotreme and therian mammals. Molecular Biology and Evolution 13(6): 798-808.

Hall, T.A. 1999. BioEdit: A user-friendly biological sequence alignment editor and analysis program for Windows 95/98/NT. Nucleic Acids Symposium Series 41: 95-98.

Huelsenbeck, J.P. \& Ronquist, F. 2001. MrBayes: Bayesian inference of phylogenetic trees. Bioinformatics 17(8): 754755.

Jansa, S.A. \& Weksler, M. 2004. Phylogeny of muroid rodents: Relationships within and among major lineages as determined by IRBP gene sequences. Molecular Phylogenetics and Evolution 31(1): 256-276.

Jiang, X., Gao, J., Ni, L., Hu, J., Li, K., Sun, F., Xie, J., Bo, X., Gao, C., Xiao, J. \& Zhou, Y. 2012. The complete mitochondrial genome of Microtus fortis calamorum (Arvicolinae, Rodentia) and its phylogenetic analysis. Gene 498(2): 288-295.

Jobb, G., von Haeseler, A. \& Strimmer, K. 2004. Treefinder: A powerful graphical analysis environment for molecular phylogenetics. BMC Evolutionary Biology 4(1): 18.

Katoh, K. \& Standley, D.M. 2013. MAFFT multiple sequence alignment software version 7: Improvements in performance and usability. Molecular Biology and Evolution 30(4): 772-780.

Kim, E.B. \& Lee, S.G. 2016. The complete mitochondrial genome of the Mongolian gerbil, Meriones unguiculatus (Rodentia: Muridae: Gerbillinae). Mitochondrial DNA 27(2): 1457-1458.

Koh, H.S., Lee, W.J. \& Kocher, T.D. 2000. The genetic relationships of two subspecies of striped field mice, Apodemus agrarius coreae and Apodemus agrarius chejuensis. Heredity 85(1): 30-36.

Kong, L., Wang, W., Cong, H., Liu, Z. \& Li, Y. 2015. Complete mitochondrial genome of the black giant squirrel Ratufa bicolor (Rodentia: Sciuridae). Mitochondrial DNA 26(5): 759-760.

Larizza, A., Pesole, G., Reyes, A., Sbisà, E. \& Saccone, C. 2002. Lineage specificity of the evolutionary dynamics of the mtDNA D-loop region in rodents. Journal of Molecular Evolution 54(2): 145-155.

Latinne, A., Waengsothorn, S., Rojanadilok, P., Eiamampai, K., Sribuarod, K. \&Michaux, J.R. 2013. Diversity and endemism of Murinae rodents in Thai limestone karsts. Systematics and Biodiversity 11(3): 323-344.

Lecompte, E., Aplin, K., Denys, C., Catzeflis, F., Chades, M. \& Chevret, P. 2008. Phylogeny and biogeography of African Murinae based on mitochondrial and nuclear gene sequences, with a new tribal classification of the subfamily. BMC Evolutionary Biology 8(1): 199.

Liu, Q., Chen, P., He, K., Kilpatrick, C.W., Liu, S.Y., Yu, F.H. \& Jiang, X.L. 2012. Phylogeographic study of Apodemus ilex (Rodentia: Muridae) in Southwest China. PLoS ONE 7(2): e31453 012 .
Medway, L. 1983. The Wild Mammals of Malaya (Peninsular Malaysia and Singapore). Kuala Lumpur: Oxford University Press.

Michaux, J., Reyes, A. \& Catzefkis, F. 2001. Evolutionary history of the most speciose mammals: Molecular phylogeny of muroid rodents. Molecular Biology and Evolution 18(11): 2017-2031.

Musser, G.G. \& Carleton, M.D. 2005. Superfamily Muroidea. In Mammal Species of the World a Taxonomic and Geographic Reference, edited by Wilson, D.E. \& Reeder, D.M. Baltimore: Johns Hopkins University Press. pp. 8941531.

Ojala, D., Montoya, J. \& Attardi, G. 1981. tRNA punctuation model of RNA processing in human mitochondria. Nature 290: 470-474.

Pagès, M., Chaval, Y., Hernerteau, V., Waengsothorn, S., Cosson, J.F., Hugot, J.P., Morand, S. \& Michaux, J. 2010. Revisiting the taxonomy of the Rattini tribe: A phylogeny based determination of species boundaries. BMC Evolutionary Biology 10(1): 184.

Pereira, S.L. 2000. Mitochondrial genome organization and vertebrate phylogenetics. Genetics and Molecular Biology 23(4): 745-752.

Purnomo \& Bangs, M.J. 1996. Breinlia tinjili sp. n. (Filarioidea: Onchocercidae), from the Malaysian Field Rat, Rattus tiomanicus, on Tinjil Island, West Java, Indonesia. Journal of the Helminthological Society of Washington 63: 93-97.

Rambaut, A. 2012. FigTree. Edinburgh: University of Edinburgh.

Robins, J.H., Tintinger, V., Aplin, K.P., Hingston, M., MatisooSmith, E., Penny, D. \& Lavery, S.D. 2014. Phylogenetic species identification in Rattus highlights rapid radiation and morphological similarity of New Guinean species. PLoS ONE 9(5): e98002.

Robins, J.H., McLenachan, P.A., Phillips, M.J., McComish, B.J., Matisoo-Smith, E. \& Rosset, H.A. 2010. Evolutionary relationships and divergence times among the native rats of Australia. BMC Evolutionary Biology 10(1): 375.

Robins, J.H., McLenachan, P.A., Phillips, M.J., Craig, L., Ross, H.A. \& Matisoo-Smith, E. 2008. Dating of divergences within the Rattus genus phylogeny using whole mitochondrial genomes. Molecular Phylogenetics and Evolution 49(2): 460-466.

Robins, J.H., Hingston, M., Matisoo-Smith, E. \& Ross, H.A. 2007. Identifying Rattus species using mitochondrial DNA. Molecular Ecology Notes 7(5): 717-729.

Ryu, S.H., Kwak, M.J. \& Hwang, U.W. 2013. Complete mitochondrial genome of the Eurasian flying squirrel Pteromys volans (Sciuromorpha, Sciuridae) and revision of rodent phylogeny. Molecular Biology Reports 40(2): 1917-1926.

Sbisà, E., Tanzariello, F., Reyes, A., Pesole, G. \& Saccone, C. 1997. Mammalian mitochondrial D-loop region structural analysis: identification of new conserved sequences and their functional and evolutionary implications. Gene 205(12): $125-140$. 
Schwarz, G. 1978. Estimating the dimension of a model. Annals of Statistics 6(2): 461-464.

Silva, A., Artiles, A., Suarez, W. \& Silva, G. 2011. Sequence and structure of the mitochondrial control region of the Cuban rodent Capromys pilorides (Rodentia: Capronyidae). Biotecnología Aplicada 28(3): 136-141.

Suzuki, H., Filippucci, M.G., Chelomina, G.N., Sato, J.J., Serizawa, K. \& Nevo, E. 2008. A biogeographic view of Apodemus in Asia and Europe inferred from nuclear and mitochondrial gene sequences. Biochemical Genetics 46(56): $329-346$

Tanabe, A.S. 2007. Kakusan: A computer program to automate the selection of a nucleotide substitution model and the configuration of a mixed model on multilocus data. Molecular Ecology Notes 7(6): 962-964.

Tucker, P.K., Sandstedt, S.A. \& Lundrigan, B.L. 2005. Phylogenetic relationships in the subgenus Mus (genus Mus, family Muridae, subfamily Murinae): Examining gene trees and species trees. Biological Journal of the Linnean Society 84(3): 653-662.

Wang, S., Cong, H., Kong, L., Morokawa, M. \& Li, Y. 2015. Complete mitochondrial genome of the greater bandicoot rat Bandicota indica (Rodentia: Muridae). Mitochondrial DNA 27(6): 4349-4350.

Yong, B., Wei, H., Jia, Q. \& Chen, S. 2016. Sequencing and analysis of complete mitochondrial genome of Niviventer fulvescens (Muridae). Mitochondrial DNA 27(5): 36503651.

Yong, H.S. 1969. Karyotypes of Malayan rats (Rodentia, Muridae, genus Rattus Fischer). Chromosoma 27(3): 245267.

Yong, H.S. 1968. A Comparative Study of the Genetics and Systematics of the Malayan Species of Rattus Fischer. $\mathrm{PhD}$ Thesis. Kuala Lumpur: University of Malaya (Unpublished).

Yong, H.S. \& Eamsobhana, P. 2013. Definitive rodent hosts of the rat lungworm Angiostrongylus cantonensis. Raffles Bulletin of Zoology 29: 111-115.

Yong, H.S. \& Dhaliwal, S.S. 1980. Immunoelectrophoretic serum-protein patterns of three commensal rats in Peninsular Malaysia. Malaysian Journal of Science 6: 5-7.
Yong, H.S., Dhaliwal, S.S. \& Tee, K.L. 1972. Chromosome studies of three Malayan island rats. Cytologia 37(3): 507511.

Zhao, F., Zhang, T., Su, J., Nevo, E. \& Lin, G. 2014. Mitochondrial genome of bamboo rat Rhizomys pruinosus. Mitochondrial DNA 25(5): 381-382.

Zhu, D., Huang, J., Kang, C., Song, X., Yue, B. \& Zhang, X. 2016. The complete mitochondrial genome of Leopoldamys edwardsi (Rodentia: Muridae). Mitochondrial DNA 27(3): 1882-1884.

Sze-Looi Song*

Institute for Advanced Studies

University of Malaya

50603 Kuala Lumpur, Federal Territory

Malaysia

Sze-Looi Song* \& Phaik-Eem Lim

Institute of Ocean and Earth Sciences

University of Malaya

50603 Kuala Lumpur, Federal Territory

Malaysia

Hoi-Sen Yong

Institute of Biological Sciences

Faculty of Science

University of Malaya

50603 Kuala Lumpur, Federal Territory

Malaysia

Ji Tan

Department of Agricultural and Food Sciences

Universiti Tunku Abdul Rahman

31900 Kampar, Perak Darul Ridzuan

Malaysia

*Corresponding author; email: szelooi@um.edu.my

Received: 26 December 2019

Accepted: 22 September 2020 